\title{
Real option valuation of game lodge concessions
}

\author{
J. Spencer-Young* \\ Syzygy Business Solutions, P.O Box 211, Rivonia, 2128, \\ Republic of South Africa \\ justin@syzygysolutions.co.za \\ F. Durand \\ Wits Business School, University of the Witwatersrand, \\ PO Box 98, Wits, 2050, Republic of South Africa
}

\section{Received October 2003}

\begin{abstract}
Recent commercialisation of property in the Kruger National Park was achieved by the tendering of various concession rights. South African National Parks generated scenarios of possible future cash flows for private lodges on the concession sites and identified what rental incomes they expected to receive from the different concessions. Following the public tender of the concessions, they found that they had grossly underestimated the value of the concession rights as the actual tender values of the winning bidders far exceeded their mean concession fee valuations.
\end{abstract}

Through the use of random stochastic modelling and Monte Carlo simulation this research shows that real option valuation accounts for the positive difference between the winning bids and the mean concession fee values for each of the concessions investigated.

*To whom all correspondence should be addressed.

\section{Introduction}

In recent years, the discounted cash flow (DCF) framework has come under fire for failing to consider the options that are embedded in many new development projects (Damodaran, 2000). The result is that managers are looking for new techniques to get them from a DCF value to the 'real' value. Kulatilaka (1984) believes that this shortfall in DCF methods gives rise to the reasons for systematic undervaluation of investments with significant operating options. He suggests that the recent extensions of option pricing theory have shown promise in overcoming the limitations of DCF methods.

Recent commercialisation of property in the Kruger National Park was achieved by the tendering of concession rights to five different properties. The South African National Parks (SANP) was responsible for this process. In order to determine the potential value of the different concession rights, SANP generated scenarios of possible future cash flows for private lodges on the concession sites. The projections were made for twenty years into the future. Based on the discounted values of these cash flows, SANP identified what rental incomes they expected to receive from the different concessions. Following the public tender of the concessions, SANP found that they had grossly underestimated the value of the concession rights. The actual tender values of the winning bidders far exceeded SANP's projections. This gave rise to a number of questions. Firstly, how did the bidders determine the price to bid for the different concessions? Secondly, why were the projections done by SANP so far out? Thirdly, can real option valuation (ROV) account for the difference in value between the DCF projections and the actual tender amount?

To answer the questions, a number of assumptions and projections were needed including:

- Future exchange rate fluctuations

- Future decline or growth in international tourism to South Africa

- International perception of political and security risks

- Health risks

- The market demand for facilities associated with game viewing and wildlife leisure

- The rate at which similar resources of this nature are declining and thus creating an element of scarcity of wildlife resources

These were the market demand and supply issues that bidders were required to make their own assumptions about. 


\section{Literature review}

\section{Real option valuation}

Decisions to proceed with capital investment projects have traditionally been made with the use of Net Present Value (NPV) calculations. Occasionally managers are faced with potential projects or investments that show negative NPVs, but based on intuition they decide to go ahead (Copeland \& Keenan, 1998).

According to Damodanan (2000), the NPV of a project does not capture the value of management's ability to expand the size and scope of a project should things work out. Furthermore, NPV calculations do not reflect the value of delaying the start of a project until conditions become more favourable. Triantis (2000) suggests that real options are opportunities to delay and adjust investments and operating decisions over time in response to the resolution of uncertainty.

According to Amran and Kulatilaka (2000), real options have value in environments of uncertainty whereas DCF methods work well when investments are expected to produce a fairly predictable set of results in a stable environment. Amran and Kulatilaka (2000) point out that we live in a period of heightened uncertainty and that our current business environment is being shaped by large scale and long-term trends such as deregulation and increased global competition, as well as the recent arrival of the Internet. They go on to say that the convergence of these factors has sparked off a search for strategic frameworks and capital budgeting tools that can help managers evaluate and manage uncertain opportunities.

According to Triantis (2001), academics started building option-based models with a view to valuing real assets around mid-1980 and laid the foundation for extensive academic literature in the field of real options. Meyers (1984) suggested that real option theory has the potential to close the gap between strategy and finance.

Triantis (2001) holds the view that real options have established a solid, yet limited, foothold in the corporate world and have emerged as an approach that addresses the challenges brought about by the need for change and flexibility in an environment of uncertainty. They see the adoption of real option techniques as a means of providing a long-term competitive advantage through better decisionmaking. Essentially they regard them as a way of thinking that can provide a language that frames and communicates decision problems quantitatively. They point out that real options can be used as an analytical tool to value projects with known, well-specified option characteristics. According to Kulatilaka and Marcus (1999), it is most important to incorporate option analysis when at least one of the following conditions exists: (1) the ultimate best operating mode or environment in the future is difficult to forecast today; (2) current uncertainty is sufficiently great that differences in profit across possible operating modes or environments are substantial; (3) switching costs between different operating modes make it difficult to condition cash flow forecasts on optimal future decisions.

\section{Why NPV and DCF valuations fall short}

Leslie and Michaels (1997) argue that NPV calculations can be misleading whenever there is flexibility involved, especially regarding flexibility to respond to uncertainty over the rate of cash flow growth. The reason suggested is because there are only two key levers of value creations, those being the present value of cash inflows and cash outflows, which are usually static. They observe that while many managers use scenario analysis techniques to capture the fact that values can exist in ranges, recognising that uncertainty exists is not enough because it must be incorporated into a valuation, which NPV scenario analysis cannot do.

According to Amran and Kulatilaka (2000), DCF's fail in cases where there is a lot of managerial discretion to modify the original plan after a project has begun. This cannot be captured at the outset by the use of DCF valuation techniques. They go on to say that managers instinctively expand operations if a project is proving to be successful or cut back if a project is unsuccessful and these are issues that cannot be accounted for when projects are initially valued.

Copeland and Keenan (1998) identify other evaluation tools that are often used in conjunction with DCFs such as decision trees, economic profit evaluations and earnings growth evaluations. All of these evaluation tools have their own shortcomings some of which are applicable to all of the different techniques. They use these shortcomings to make a strong argument for real option valuation based on the fact that real option valuation accounts for flexibility.

How real option valuation works

According to Hull (2000), most investment projects involve options. These options can add considerable value to a project, but are often either ignored or valued incorrectly. He gives the following examples of embedded options:

- The option to abandon

- The option to expand

- The option to downscale

- The option to wait or delay

- The option to extend

There are a variety of techniques used to value options, including the Black and Scholes (1973) model, the binomial or other 'lattice' option pricing models, Monte Carlo simulation and risk adjusted decision trees (Triantis, 2001). The Black and Scholes (1973) model was initially designed to price European options in financial markets. It is the model most commonly used when it comes to valuing real options (Damodaran, 2000). According to Benninga (2001), it is numerically by far the easiest and most suited model that exists for valuing options of any kind.

Luehrman (1998) provides the following table for mapping a real options investment opportunity onto a call option: 
Table 1: Mapping an investment opportunity onto a Black and Scholes (1973) call option

\begin{tabular}{|c|c|c|}
\hline Investment opportunity & Variable & Call option \\
\hline $\begin{array}{l}\text { Net present value of } \\
\text { project's cash flows to be } \\
\text { acquired if the project were } \\
\text { to proceed under current } \\
\text { conditions }\end{array}$ & $\mathrm{S}$ & Stock price \\
\hline $\begin{array}{l}\text { Expenditure needed to } \\
\text { acquire the projects assets. } \\
\text { This is also referred to as } \\
\text { the capital investment and } \\
\text { or the present value of all } \\
\text { future payment required to } \\
\text { secure the rights }\end{array}$ & $\mathrm{X}$ & Exercise price \\
\hline $\begin{array}{l}\text { Length of time the decision } \\
\text { may be deferred or the } \\
\text { length of time for which the } \\
\text { rights are held }\end{array}$ & $\mathrm{t}$ & $\begin{array}{l}\text { Time to } \\
\text { expiration }\end{array}$ \\
\hline $\begin{array}{l}\text { Time value of money } \\
\text { applicable to the project }\end{array}$ & $\mathrm{Rf}$ & Risk free rate \\
\hline $\begin{array}{l}\text { Riskiness of the project } \\
\text { assets based on the } \\
\text { probability of the } \\
\text { occurrence of future events } \\
\text { or developments that are } \\
\text { difficult to forecast with any } \\
\text { degree of certainty }\end{array}$ & $\sigma^{2}$ & $\begin{array}{l}\text { Variance of } \\
\text { returns on } \\
\text { stock }\end{array}$ \\
\hline
\end{tabular}

\section{Source: Luehrman (1998: 52).}

\section{The successful use of real option valuation}

Real option applications have a variety of contexts, such as in natural resource investments, land development, leasing, flexible manufacturing, government subsidies and regulation, $\mathrm{R} \& \mathrm{D}$, new ventures and acquisitions, foreign investment and strategy (Trigeorgis, 1993).

Early applications arose in the area of natural resource investments due to the availability of traded resources or commodity prices, high volatilities and long durations, resulting in higher and better option value estimates (Trigoergis, 1993). Brennan and Schwartz (1995) first utilised the convenience yield derived from futures and spot prices of a commodity to value the options to shut down or abandon a mine. Paddock, Siegel, and Smith (1998) valued options embedded in undeveloped oil reserves and provided the first empirical evidence that option values are better than actual DCF-based bids in valuing offshore oil leases. Kester (1984) estimated that the value of a firm's growth options is more than half the market value of equity for many firms, even $70 \%-80 \%$ for more volatile industries. Similarly, Pindyck (1991) also suggested that growth options represent more than half of firm value if demand volatility exceeds $20 \%$.

In the area of land development Williams (1991), Capozza and Sick (1992), Quigg (1993) and Titman (1995) showed that the value of vacant land should reflect not only its value based on its best immediate use (e.g. from constructing a building now), but also its option value if development is delayed and the land is converted into its best alternative use in the future. Similar arguments apply to concession rights.

Real option theory has been applied to valuing resource concession rights particularly in the case of oil and gas resources (Smith \& McCardle, 1999). The main difference between valuing the oil and gas resource concessions and land or game lodge concessions is that these involve more down-stream management decisions with regard to production output.

According to Damodaran (2000), the variance of the present value of future cash flows can be estimated in three ways:

1. Using the variance of the cash flows from similar projects.

2. Assigning probabilities to various market scenarios and estimating the variances between the different scenarios.

3. Applying the market values of companies involved in the same business as the project.

In the case of concession rights valuation, certain market elements can affect the volatility of the underlying asset and hence the value of the embedded option. According to Tisdale (1987), the elements that most influence investors when considering entry into foreign tourism markets are the effect of fluctuations in currency values, the political risk associated with the country especially in developing markets and the potential for tourism growth in that country. As additional factors, land ownership risks and health risks have been included as recommended by Wilson, du Plessis and Piet (2000).

Modelling as a tool for determining revenue distributions and their volatility based on the underlying variables

According to Jenkins (2000) the Black and Scholes (1973) model had the effect of revolutionising the options market in the 1970's and encouraged its rapid expansion by reducing very complex data to a single value by which people could reliably trade. He goes on to tell how pioneers of computer modelling claim that they provide a similar service by modelling risk. Using this approach the distributions of a number of outputs including: gross revenue, concession fee payments, NPVs and even real option valuations based on NPV distributions could be used to model concession rights.

Smith and McCradle (1999) note that the key to developing a dynamic programming model is to identify a reasonably small set of decision variables that are sufficient to describe the bulk of the value of the project over time. They suggest the use of simulation as a means of determining output distributions associated with these decision variables and show that evaluating the flexible variables in a model requires one to determine low, medium and high scenarios. As an alternative they suggest normal, triangular or uniform distributions depending on the nature of the variable. 


\section{Proposition}

To explain the difference between the expected and actual results of the tenders the following proposition was tested.

The real option values of the SANP concession rights reflect the positive difference between the expected mean concession fee values and the actual values obtained via public tender.

\section{Research methodology}

\section{Population and sample}

The population was made up of the winning bidders for the five concession rights tendered by SANP. The details of the winning bidders for the relevant concession sites were as follows:

Winning bid for concession right 1 :

Mpanamana

Present value of the winning bid:

R 44,982,260

Present value of the SANP minimum expectation:

R 32,450,847

Winning bid for concession right 2: Jock of the Bushveld Present value of the winning bid: R 23,006,163

Present value of the SANP minimum expectation:

R 4, 235, 485

Winning bid for concession right 3 :

Present value of the winning bid:

Lwakahale

Present value of the SANP minimum expectation:

R 14,029,658

R 13,521,186

Winning bid for concession right 4 :

Present value of the winning bid:

Mluwati

Present value of the SANP minimum expectation:

R 32,295,037

Winning bid for concession right 5 :

Present value of the winning bid:

Nwanetsi

Present value of the SANP minimum expectation:

R $16,602,36$

The winning bid submissions included the calculated concession fees that the bidder was tendering. In some cases the information in the bid documentation included the capital expenditure, the estimated cost of capital for the project and the operational cost structure. Where the information was not available industry norms were used and suitable approximations of these values were made. The cost of capital used in the models was taken as the cost of equity, so that it was assumed that the ventures were fully financed by equity.

\section{Data analysis and model development}

To understand the financial bidding system and the methodology used by SANP and the bidders, a Microsoft Excel-based discounted cash flow (DCF) Real Option model was developed, incorporating all the aspects relevant to each concession. Its purpose was to describe all the possible revenue distributions that could result from the underlying characteristics of each of the concession sites and determined a distribution of feasible concession fee bids.

The model then determined the distribution of feasible net present values (NPVs) for the relevant concessions and these underlying inputs together with years to expiry and the risk free rate were used to determine a distribution of option values for the concession right. The total revenue plus the additional revenue was used in calculating the option price and the real option value was obtained by subtracting the NPV from the option price (Benninga, 2001: 331).

The DCF Real Option model used the principles advocated by Smith and McCardle (1999). It incorporates Monte Carlo simulation from which the different distributions were determined. Approximately six thousand simulations for each concession based on the outputs from the random stochastic variables. Comparisons were then made between the mean real option values, the mean concession fee values and the differences between the SANP expected bids and the winning bids. It was then determined if the winning bidders paid more or less than the mean real option value over and above what the NPV, or if they didn't pay any of the real option value at all. The actual variables, the relationship between them and the modelling structure are described below.

Revenue calculation:

Cost per night $\mathrm{x}$ Number of beds $\mathrm{x}$ Occupancy levels $\mathrm{x}$ Nights per year + Additional revenue

Cost per night:

This was the rate charged to customers staying at the lodge. A triangular distribution was used to model this variable which was then impacted on by an additional random variable for exchange rates and tourism growth.

Number of beds:

The maximum number of beds for each concession site was prescribed by SANP. The number of beds prescribed included those required to accommodate both clients and staff. It was left up to the bidders to determine what their split would be between client and staff beds based on their lodge model.

Occupancy levels:

This was the key issue in determining the financial success of the concessions. It was measured as a percentage, $100 \%$ meaning that every bed was full every night of the year. Occupancy levels vary through the year with seasons and holiday periods. For the purpose of the calculation an average for the year was taken. A normal distribution was used to model this variable with the impact of an additional random variable for exchange rate and tourism growth.

Nights per year:

For the purpose of the calculation this was assumed to be 365 as the lodges trade all year round. 
Additional revenue:

Lodges expect to make additional revenue from selling augmented services and products to guests and visitors to the lodge. This was based on what was offered by the different lodges and calculated as a percentage of the gross revenue.

Generic variables:

The generic variables are those variables that were applicable to all of the concession rights where the input data did not change from one concession right to the other. These variables were external factors that were uncontrollable by the bidders. Examples of these variables are the exchange rate and inflation. The generic variables and their inputs are described in Table 2.

Table 2: Generic variables and input data

\begin{tabular}{|c|c|}
\hline Variable & Modelling formula and input data \\
\hline \multirow{5}{*}{ Exchange rate } & NORMINV(RAND(),Mean,StdDev))* \\
\hline & DepreciationFactor \\
\hline & Mean $=$ R7.55 \\
\hline & StdDev $=0.75 \%$ \\
\hline & Dep factor $=8 \%$ \\
\hline \multirow{3}{*}{ Inflation } & NORMINV(RAND(),Mean,StdDev)) \\
\hline & Mean $=3 \%$ \\
\hline & StdDev $=0.5 \%$ \\
\hline \multirow{4}{*}{$\begin{array}{l}\text { Additional } \\
\text { revenue }\end{array}$} & NORMINV(RAND(),Mean,StdDev))* \\
\hline & GrossProfit \\
\hline & Mean $=5 \%$ \\
\hline & StdDev $=1 \%$ \\
\hline \multirow{2}{*}{$\begin{array}{l}\text { Bed nights per } \\
\text { year }\end{array}$} & Single number \\
\hline & Days per year $=365$ \\
\hline
\end{tabular}

\section{Presentation of results}

The DCF Real Option model consists of the following spreadsheets and charts:

- DCF model

- Gross revenue and concession fee simulation

- NPV simulation

- Real Option simulation

- Simulation summaries

- Revenue chart

- Concession fee chart

- NPV chart

- Real Option chart

- Simulation results

In order to show the outputs generated by the DCF Real Option model an abridged model for Concession right 5 (Nwanetsi) has been included in this section.
Gross revenue chart (Nwanetsi - concession right 5)

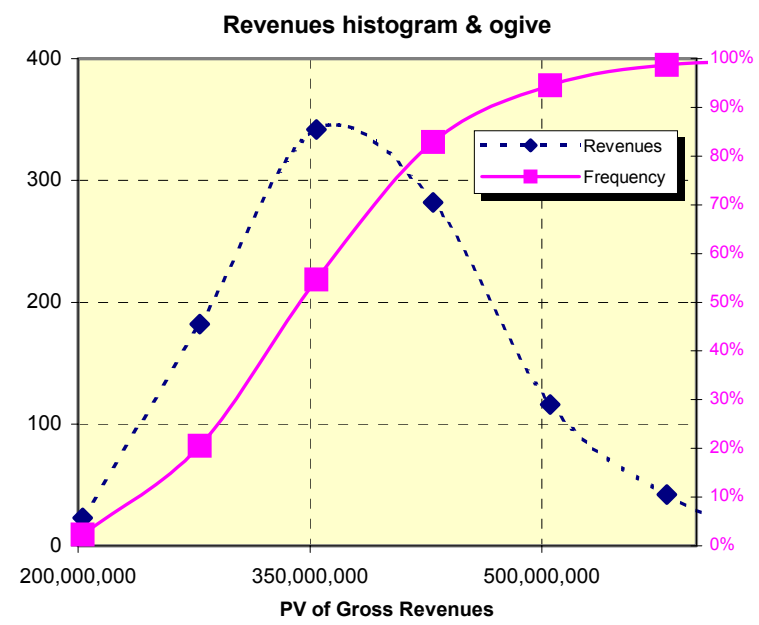

Figure 1: Distribution of the present value of the gross revenue

The distribution of gross revenues shown in Figure 1 are all the possibilities that resulted out of approximately 6000 simulations all with different scenarios playing out. These different scenarios were randomly generated and reflect the impact that the major variables have on the potential revenue generation from the concession site.

\section{Concession fee chart (Nwanetsi - concession right 5)}

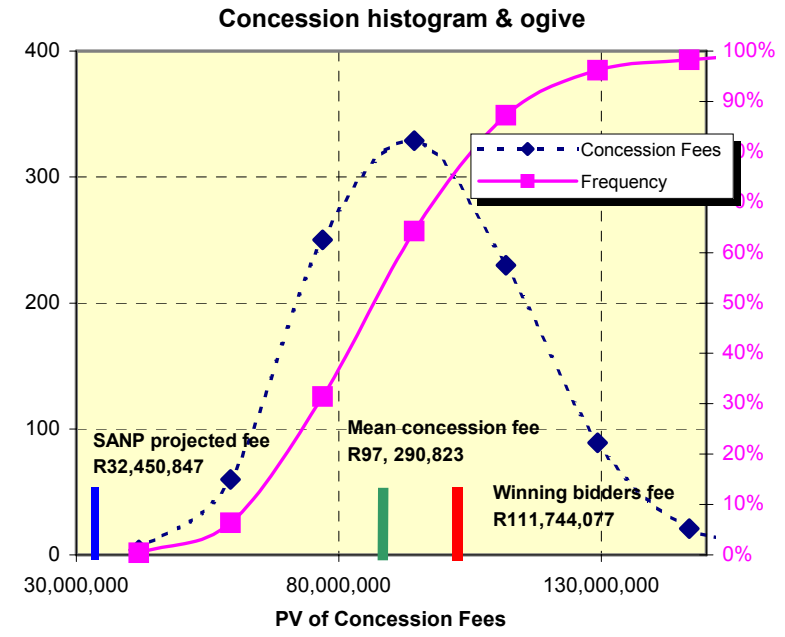

Figure 2: Distribution of the present value of the concession fee

Using the distribution of gross revenues, a distribution of concession fees was determined by applying the SANP prescribed formula. It can be seen that Figure 2 is directly proportional to Figure 1 due to the fact that a linear formula has been applied to the gross revenue results. 
NPV chart (Nwanetsi - Concession right 5)

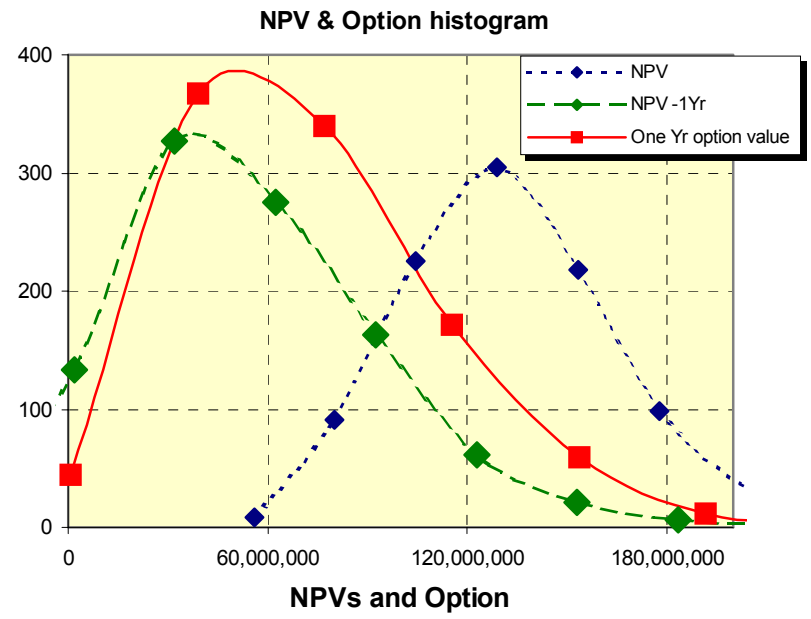

Figure 3: Distribution of the NPV's and option values

Figure 3 shows the NPV (dotted blue curve) of the concession based on the fact that it starts generating income from year one. The dotted curve represents the 19-year NPV on the basis that the potential revenue from year 20 was excluded (i.e. assuming the first year would be spent developing the lodge). The solid curve represents the option value of the concession based on the 19 year NPV. The real option value is determined by the difference between these two curves. For example the apex the solid curve is approximately R15,000,000 more than the apex of the dotted curve. This difference is represented in Figure 4.

\section{NPV chart (Nwanetsi - Concession right 5)}

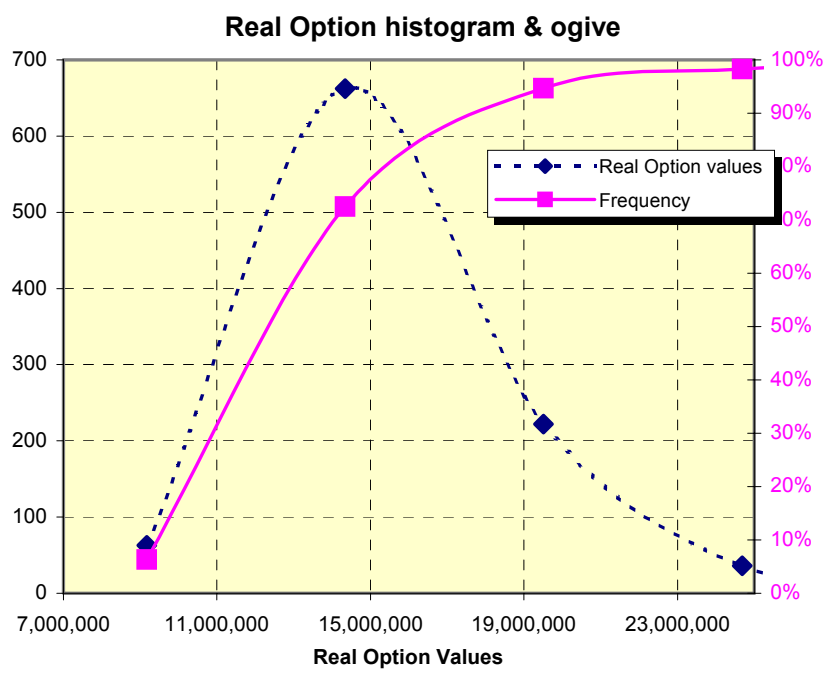

Figure 4: Distribution of the NPV's and option values

Figure 4 represents the distribution of real option values that are embedded in the concession site, the result of multiple scenarios of varying exchange rates, tourism growth rates, occupation rates etc. This is the value of the flexibility of all the variables that could impact on the site that are not accounted for in the NPV calculations. Using this information developers can take a view on how much extra they are prepared to bid for a site and feel comfortable that the predicted profit streams are still acceptable.

\section{Final results - Concession right 5 (Nwanetsi)}

The winning bid for this concession right was R111,744,077. The calculated mean concession fee for this concession was R97,290,823. The difference between the winning bid and the mean concession fee is R14,453,254. The calculated mean real option value for this concession right is $\mathrm{R} 15,745,158$. The mean real option value therefore represented $100 \%$ of the difference between the winning bid and the mean concession fee.

\section{Summary of results}

The following table contains a summary of all the results:

Table 3: Results summary

\begin{tabular}{|c|c|c|}
\hline Concession name & Description & Result \\
\hline \multirow{5}{*}{$\begin{array}{l}\text { Concession right } 1 \\
\text { (Mpanamana) }\end{array}$} & Winning bid & R 44,982,260 \\
\hline & Mean concession fee & R 37,369,589 \\
\hline & Difference & R 7,612,671 \\
\hline & $\begin{array}{l}\text { Mean real option } \\
\text { value }\end{array}$ & R 5,137,435 \\
\hline & \% Representation & $68 \%$ \\
\hline \multirow{5}{*}{$\begin{array}{l}\text { Concession right } 2 \\
\text { (Jock of the } \\
\text { Bushveld) }\end{array}$} & Winning bid & R 23,006,163 \\
\hline & Mean concession fee & R $13,140,411$ \\
\hline & Difference & R $9,865,752$ \\
\hline & $\begin{array}{l}\text { Mean real option } \\
\text { value }\end{array}$ & R 2,075,862 \\
\hline & $\%$ Representation & $21 \%$ \\
\hline \multirow{5}{*}{$\begin{array}{l}\text { Concession right } 3 \\
\text { (Lwakahle) }\end{array}$} & Winning bid & R $14,029,658$ \\
\hline & Mean concession fee & R $10,516,505$ \\
\hline & Difference & R 3,513,153 \\
\hline & $\begin{array}{l}\text { Mean real option } \\
\text { value }\end{array}$ & R 2,439,801 \\
\hline & \% Representation & $70 \%$ \\
\hline \multirow{5}{*}{$\begin{array}{l}\text { Concession right } 4 \\
\text { (Mluwati) }\end{array}$} & Winning bid & R 55,074,613 \\
\hline & Mean concession fee & R 44,392,745 \\
\hline & Difference & R 10,681,868 \\
\hline & $\begin{array}{l}\text { Mean real option } \\
\text { value }\end{array}$ & R 7,071,070 \\
\hline & \% Representation & $70 \%$ \\
\hline \multirow[t]{5}{*}{$\begin{array}{l}\text { Concession right } 5 \\
\text { (Nwanetsi) }\end{array}$} & Winning bid & $\begin{array}{l}\mathrm{R} \\
111,744,077 \\
\end{array}$ \\
\hline & Mean concession fee & R 97,290,823 \\
\hline & Difference & R $14,453,254$ \\
\hline & $\begin{array}{l}\text { Mean real option } \\
\text { value }\end{array}$ & R $15,745,158$ \\
\hline & \% Representation & $100 \%$ \\
\hline
\end{tabular}

\section{Interpretation of results}

In tendering the concession rights in the Kruger National Park, SANP realised the importance of rating the tenders based on a number of criteria. These criteria included: black empowerment, social up-liftment of the surrounding 
community, commitment to nature conservation and the financial bid. It is important to acknowledge that the strength of the financial bid was not the sole criterion for winning the tender. This meant that the influence of other factors may have resulted in the concession being won by a bidder who did not make the highest financial bid, but who complied with all the criteria in order to have a better bid overall.

All the winning concession fee bids were higher than the mean concession fees calculated using the DCF real option model. The fact that there was a positive difference between the mean concession fees and the winning bids gave the research proposition validity. It also indicated that the winning bidders 'had a feeling' that there was some underlying value in the concession rights that had to be priced into their bid.

The DCF real option model determined that there was real option value in all of the five concession rights and that all of the wining bids were higher than the mean concession fee plus the mean real option value. This meant that all of the winning bidders paid more than could be justified by traditional NPV valuation techniques to secure the concession rights.

Other factors influencing the bids could have been physical location, bidding competition and over estimation of the underlying value by the bidders. Some concession sites may be located in areas that are more accessible or have a better game-viewing environment. The value that can be attached to these types of issues is not tangible to the extent that it can be included in a model of this nature, however, it can be significant enough to cause a bidder to inflate its bid in order to secure the concession rights to a particular site.

As there were only a limited number of concession rights available, a scarcity factor was introduced, which could have had the effect of inflating bids. Finally, the valuation techniques used by bidders may not have been sophisticated. If 'gut feel' was used to add to the bid over estimation may have occurred. A topic for further research would be to examine the values that game lodge developers/operators attach to these factors when bidding for concession rights.

\section{Conclusions}

The real option value attached to the concession rights that were tendered by SANP accounted for at least $68 \%$ of the difference between the winning bids and the mean concession value in four out of the five cases. Where the information submitted by the winning bidder was most comprehensive the real option value accounted for $100 \%$ of the difference between the winning bid and the mean real option value.

Considering the results of this research in terms of the proposition, it is reasonable to conclude that the proposition is true. The positive difference between the mean concession values and the winning bids is largely represented by the real option value of the concessions. Organisations like SANP could benefit by incorporating the approach used here to ensue they obtain a suitable fee for future concession rights that they put out to tender.

\section{References}

Amran, M. \& Kulatilaka, N. 2000. 'Strategy and shareholder value creation: The real options frontier', The Journal of Applied Corporate Finance, 13(2):15-17.

Aggarwal, R. 1991. 'Justifying investments in flexible manufacturing technology’, Managerial Finance, 17: 77-88.

Asia Today International. 2003. 'SARS, the financial impact', April 27-33.

Baldwin, C. Y. 1982. 'Optimal sequential investment when capital is not readily reversible', Journal of Finance, 37: 763-782.

Black, F. \& Scholes, M. 1973. 'The pricing of options and corporate liabilities', Journal of Political Economy, MayJune: 637-659.

Bell, G. 1995. 'Volatile exchange rates and the multinational firm: Entry, exit, and capacity options'. In Trigeorgis, L. (Ed.). Real Options in capital investment, 163-181. New York: Praeger.

Benninga, S. 2001. Financial modelling. 2nd Edition. Cambridge, Massachusetts: The MIT Press.

Bloom, J. \& Liebold, M. 1994. 'Challenges for the South African tourist industry to the year 2010,' South African Journal of Business Management, 25:127-136.

Brennan, M. \& Schwartz, E. 1995. 'Evaluating natural resource investments', Journal of Business, April:135-157.

Capozza, D. \& Sick, G. 1992. 'Risk and return in land markets'. Working Paper, University of British Columbia.

Copeland, T. \& Keenan, P. 1998. 'How much is flexibility worth?' The Mckinsey Quarterly, 2:38-49.

Creswell, J. W. 1994. Research design: Qualitative \& quantitative approaches. London: SAGE Publications.

De Jaarger, R. B. 2001. 'Real option valuation in the television industry'. Unpublished MBA Research Report, Johannesburg, University of the Witwatersrand.

Damodaran, A. 2000. 'The promise of real options', Journal of Applied Corporate Finance, 13(2):29-35.

Hull, J.C. 2000. Options, futures, \& other derivatives. Fourth Edition. Toronto: Prentice Hall International, Inc.

Jenkins, W. 2000. 'Sculpting the future of risk', Reactions, 8(6):22.

Kenma, A. G. Z. 1993. 'Case studies on real options', Financial Management, 22 (Autumn):259-270. 
Kester, W. C. 1984. 'Today's options for tomorrow's growth, Harvard Business Review, March-April: 153-160.

Kogut, B. \& Kulatilaka, N. 1994. 'Operating flexibility, Global manufacturing, and the option value of a multinational network', Management Science, 40:123-139.

Kulatilaka, N. 1984. 'Financial, economic and strategic issues concerning the decision to invest in advanced automation', International Journal of Production Research, 22(6): 949-968.

Kulatilaka, N. \& Marcus, A. 1992. 'Project valuation under uncertainty', Journal of Applied Corporate Finance, Fall: 92-100.

Leggat, P.A. \& Klein, M. 2001. 'Personal safety advice for travellers abroad', Travel Med, 8: 46-51.

Leslie, K. \& Michaels, M. 1997. 'The real power of real options', The $M^{C}$ Kinsey Quarterly, 3: 99-108.

Lind, D.A., Mason, R.D. \& Marchal, W.G. 2000. Basic statistics for business and economics. 3rd Edition. Boston: Irwin McGraw-Hill.

Luerhman, T. 1998. 'Investment opportunities as real options: getting started on the numbers', Harvard Business Review, July - August: 51.

Myers, S. C. 1984. 'Finance theory and financial strategy,' Interfaces, 14 (January-February): 126-137.

Paddock, J., Siegel, D. \& Smith, J. 1998. 'Option valuation of claims on physical assets: The case of offshore petroleum leases', Quarterly Journal of Economics, August: 479-508.

Pindyck, R. S. 1991. 'Irreversibility, uncertainty, and investment', Journal of Economic Literature, 26, September: 1110-1148.

Pirow, P.C. 1990. How to do business research. Juta's Publishers Information Series, Johannesburg: Juta.

Quigg, L. 1993. 'Empirical testing of real option pricing models', The Journal of Finance, XLVIII(2):6-21.

Republic of South Africa. 1994. Restitution of Land Rights Act, Government Gazette, Pretoria: Government Printer.

South African National Parks. 2001. Concession contract of the Kruger National Park, 2001. Pretoria: Internal publication.

South African Tourism Board. 2002. A survey of South Africa's international tourism market. Pretoria, SA Tourism Board.

Sick, G. 1989. Capital budgeting with real options. Monograph Series in Finance and Economics, Stern School of Business, of New York University.
Smith, J. E. \& McCardle, K. F. 1999. 'Options in the real world: Lessons learnt from valuing oil and gas investments', Operations Research, 47(1): 1-15.

The Concise Oxford Dictionary. 1964. Oxford University Press, Ely House, London, 5, 250.

The Sunday Times. 2002. 'Bumper festive season for SA'. 29 December: 1.

Tisdell, C.A. 1987. 'Tourism, the environment and profit', Economic Analysis \& Policy, 17(1): 13-30.

Titman, S. 1995. 'Urban land prices under uncertainty', American Economic Review, June: 505-514.

Triantis, A. 2001. 'Real options: State of the practice', Journal of Applied Corporate Finance, 14(2):8-23.

Trigoergis, L. 1993. 'Real options and interactions with financial flexibility', Financial Management, Autumn: 22, 202-225.

Williams, J. 1991. 'Real estate development as an option', Journal of Real Estate Finance and Economics, June:191208.

Wilson, P.J., Du Plessis, P.G. \& Piet, G. 2000. 'Land claims of indigenous peoples, the impact on property values', Journal of Real Estate Literature, 8(1): 35. 